\title{
Třídní učitel v sociálních vztazích se svými žáky: případová studie ${ }^{1}$
}

\author{
Alena Bendová \\ Masarykova univerzita, Pedagogická fakulta, Katedra pedagogiky \\ Redakci zasláno 6. 11. 2015 / upravená verze obdržena 10. 4. 2016 / \\ k uveřejnění přijato 16. 4. 2016
}

\begin{abstract}
Abstrakt: Cílem předkládané studie je analyzovat determinanty dobrého vztahu mezi třídním učitelem a žáky na střední odborné škole. Zaměřujeme se při tom na osobu třídní učitelky. V první části jsou vymezena teoretická východiska. Vycházíme hlavně z výzkumů expertnosti učitele a výzkumů vztahů mezi učitelem a žáky. V druhé části př́íspěvku jsou představeny dílčí výsledky případové studie středoškolské tř́idy s dobrým sociálním klimatem, jež se týkají výhradně zkoumané třídní učitelky. Vzorek tvořilo 24 studentů a třídní učitelka. Na základě analýzy dat byly u učitelky identifikovány jednak osobnostní předpoklady $\mathrm{k}$ budování optimálního vztahu s žáky (mateřská starostlivost a vřelost, extroverze a zdravé sebevědomí, životní zkušenosti a mladistvost), jednak charakteristické interpersonální chování k žákům (expresivní komunikace, podněcování, povzbuzování, neformální vedení výuky, péče a podpora, otevřené vyjadřování emocí, naslouchání a sdílení osobních informací a uplatňování vlivu).
\end{abstract}

Klíčová slova: tř́ídní učitel, sociální vztah, žáci, expert

V souvislosti se změnami v současném školství je kladen stále větší důraz na učitele, na jeho osobnostní vybavení a schopnost komunikace. Vzhledem $\mathrm{k}$ roli třídního učitele nabývají tyto charakteristiky ještě většího významu. Ačkoliv jeho velmi významnou rolí je mimo jiné koordinovat práci s jinými pedagogy a komunikace $s$ rodiči, v předkládané studii akcentujeme hlavně jeho úlohu směrem do tř́́dy, tj. k žákům. Cílem studie je analyzovat determinanty dobrého vztahu mezi třídní učitelkou a žáky na střední odborné škole. Optimálním vztahem mezi třídním učitelem a žáky chápeme takový vztah, $\mathrm{v}$ němž je minimalizována asymetričnost ve vztahu mezi učitelem a žáky a učitel je schopen navázat blízký vztah s žáky (viz Pelikán, 2002). V tomto článku prezentujeme dílčí data týkající se třídního učitele, která jsou součástí případové studie středoškolské třídy s dobrým sociálním klimatem.

1 Vznik studie byl podpořen z projektu MUNI/A/1438/2014 Výzkum školního vzdělávání: výukové metody, didaktické prostredky a učební podmínky (SKOLA 2015). 


\section{Teoretická východiska}

\subsection{Tř́lní učitel jako expert}

Zatímco na učitele je pedagogický výzkum cílen od nepaměti, třídní učitel se v českém výzkumném prostředí přiliš velké oblibě, zvláště v posledních letech, netěší. Práce týkající se třídního učitele se věnují vymezení povinností, prestiži, vztahu s rodiči, pracovní zátěži apod. (např. Blížkovský, 1966; Spousta, 1993; Střelec, 1999; Střelec \& Krátká, 2006, 2007, 2011). Ačkoliv jsme si vědomi, že role učitele a třídního učitele jsou v mnohém totožné, rozdíl podle nás spočívá hlavně v akcentování sociálních rolí u třídního učitele. Spolu s Loudovou (2012) se domníváme, že tyto role spočívají zejména v ovlivňování vztahů mezi žáky ve tř́dě a v působení na rozvíjení osobnostního potenciálu jednotlivých žáků, v podílení se na utváření sociálního klimatu ve školní třídě, v podpoře pozitivních sociálních vztahů ve školní třídě, $\mathrm{v}$ podpoře intrapersonálního rozvoje žáka, $\mathrm{v}$ reflektování rodinného zázemí žáka, ve spolupráci s rodiči, v koordinaci a integraci mnoha výchovných úkolů. $\mathrm{V}$ této studii vycházíme teoreticky hlavně $\mathrm{z}$ výzkumů interpersonálního chování učitelů a dílčích výzkumů expertnosti, které s naším tématem úzce souvisejí.

V pedagogické literatuře se můžeme setkat s pojmy efektivní učitel, kompetentní učitel, zkušený učitel, učitel expert apod. Ačkoliv tyto pojmy mohou být pojímány různě, společné je jim akcentování kvality a kvalitního vyučování. V českém prostředí se celá řada autorů zabývala kompetencemi učitele, např. Spilková (2001), Helus (2001), Walterová (2001), Vašutová (2004), Švec a kol. (2002). Jádro kompetencí třídního učitele je podle našeho názoru v sociálních a personálních kompetencích. Švec a kol. (2002, s. 77) tyto kompetence pojímá jako schopnost optimálně jednat v různých sociálních situacích. Vališová (2004, s. 49) hovoří o přiměřeném použití motorických, duševních a emocionálních způsobů chování. Spilková a Vašutová (2008, s. 266) mluví v této souvislosti o schopnosti empatie, pochopení emocí, asertivitě, prosazování vlastních názorů, prosociálnosti. Všichni uvedení autoři se též shodují na tom, že součástí této kompetence je i schopnost budovat dobrý vztah mezi učitelem a žákem.

V našem prostředí je stále častěji zmiňován učitel expert. Švaříček (2009) definuje experta jako „kvalifikovaného, zkušeného, kvalitního učitele, který je pro okolí zároveň profesní autoritou“ (s. 21). Domníváme se, že 
nejvýznamnější determinantou kvality třídního učitele v našem prostředí vzhledem k jeho funkci jsou jeho osobnostní charakteristiky. Pro nás jsou inspirativní právě takové konceptualizace expertnosti, které kladou důraz na tyto oblasti.

V souladu s tímto pojetím považujeme za důležité identifikovat specifické osobnostní rysy a charakterové vlastnosti umožňující profesní rozvoj u tř́́dního učitele. Jedním z modelů osobnosti, který lze uplatnit i pro zkoumání tř́́dního učitele, je tzv. velká pětka (Big five nebo Five-factor model). Tento model se stal dominantním rámcem pro měření osobnosti a je důsledkem přechodu od složitějších empirických šetření k jednodušším měřením důležitých dimenzí osobnosti. Jedná se o 5 dimenzí, a to přívětivost (agreeableness), svědomitost (consientiousness), emoční stabilitu (emotional stability), extroverzi (extraversion) a otevřenost vůči zkušenosti (opennes to experience; Jacob et al., 2009, s. 9). Dalším inspirativním modelem může být i tzv. cibulový model (onion model). Jde o 5 vzájemně propojených vrstev učitelovy osobnosti (viz Korthagen, 2004; Korthagen \& Vasalos, 2005).

Významnou roli hrají u třídního učitele též charakterové a morální vlastnosti. Socket (1993, cit. podle Píšová et al., 2011, s. 93) identifikoval 5 základních ctností učitele, a to čestnost, odvahu, starostlivost, spravedlivost a praktickou moudrost. Píšová a kol. (2011) zdůrazňují, že „zatímco kognici je v souvislosti s expertností učitele a jejím rozvojem a udržováním věnována velká pozornost, mnohem méně jsou probádány oblasti emocionálních, volních, postojových a etických aspektů rozvoje expertnosti“ (s. 93).

Domníváme se, že klíčovou roli ve vztahu mezi třídním učitelem a žáky hrají emoce, jejich vyjadřování, ale i jejich zvládání. Na emoce ve školní třídě se zaměřují Suttonová a Wheatley (2003). Ti se v rámci své přehledové studie zaměřili na emoce učitelů - pozitivní i negativní. Z pozitivních emocí se nejčastěji objevují „láska a starostlivost, radost, potěšení, uspokojení, jejichž zdroji jsou především pokrok žáků, vztah s žáky, spolupráce žáků, ale také splnění všech úkolů a jiné. Zároveň ale také byly zaznamenány emoce negativní." (Sutton \& Wheatley 2003, cit. podle Píšová et al., 2011, s. 94). V souvislosti s emocemi lze zmínit i emoční kompetence učitele (např. Zins et al., 2004). Autoři zdůrazňují, že sociálně a emočně kompetentní učitelé disponují vysokým sebevědomím, znají svoje emoce a vědí, jakým způsobem je využít. Takoví učitelé dokáží správně odhadovat svoje silné i slabé stránky (Jennings \& Greenberg, 2009). Další důležitou součástí učitelových 
kompetencí je rozpoznat emoce žáka. Souhlasíme s tím, že jen tak je schopen jej motivovat a reagovat na jeho individuální potřeby (Jennings \& Greenberg, 2009). To je zvláště u třídního učitele velmi významné. U úspěšných učitelů je často identifikována velká citlivost a vřelost. Existují výzkumy, které dokazují, že učitelova vřelost a citlivost přispívají ke zdravým vztahům mezi učitelem a žáky a také k pozitivnímu třídnímu klimatu (např. Pianta et al., 2002). Všechny tyto charakteristiky by měly být v ideálním případě součástí osobnosti třídního učitele.

\subsection{Vztahy mezi žáky a třídním učitelem}

Vycházíme z toho, že vztah mezi třídním učitelem a žáky má zásadní vliv na postoje žáků k třídnímu učiteli, ale i mezi žáky navzájem a ke škole vůbec (srov. Čáp \& Mareš, 2001). Existuje řada výzkumů dokládajících důležitost dobrých vztahů mezi učiteli a žáky, nejčastěji v souvislosti s dosahováním lepších vzdělávacích výsledků žáků, chováním žáků nebo s tvorbou dobrého sociálního klimatu třídy (školy). Zásadní vliv na vztah mezi učitelem a žákem má učitelovo interpersonální chování. Wubbels a Levy (1993) potvrdili význam chování učitelů. Mnoho výzkumů dokládá, že žákovo vnímání učitelova interpersonálního chování je dủležitým faktorem pro vysvětlení kognitivních a afektivních výsledků žáků (např. Wubbels \& Levy, 1993; den Brok et al., 2002; Fisher, den Brok, \& Rickards, 2006). Z učitelova chování k žákům vyplývá i určité chování žáků k sobě navzájem. Kvalita interpersonálního chování učitele a vztah k žákům je indikátorem kvality vedení třídy. Ukazuje se, že v tomto smyslu je dobré, „vybalancovat“ kontrolu (dominanci) nad žáky a svobodu žáků (Khine \& Lourdusamy, 2006). Interpersonální chování učitele a žáků je tedy vnímáno jako důležitý faktor související se stavem a uspořádáním vztahů ve třídě. Toto interpersonální chování je zkoumáno prostřednictvím analýzy komunikace. Leary (1957) věřil, že komunikace je indikátorem osobnosti jedince. Interakčním stylem učitele nazýváme relativně trvalé prvky, vlastnosti, interakce, které se opakují a projevují se pravidelností (Gavora, 2005, s. 45). Ve studiích zabývajících se interakčními styly učitelů se nejčastěji mluví o dvou dimenzích: jednak o dimenzi vlivu (influence), která odpovídá na otázku, kdo kontroluje komunikaci (učitel nebo žák), jednak o dimenzi blízkosti (proximity), jež se ptá, zda žáci a učitel kooperují, nebo jsou spolu v opozici (viz Khine \& Lourdusamy, 2006). Výzkumníci mapují interakční styl většinou pomocí modelu, který v sobě zahrnuje osm základních charakteristik (Wubbels, Créton, \& Hooymayers, 1987). Analýza těchto dimenzí je možná prostřednictvím dotazníku The questionaire on teacher - student interaction 
(QTI), který zprostředkuje interpersonální chování učitele a interakci s jeho žáky ve třídě. Pokud mluvíme o ideální podobě interakčního stylu, někteří autoři jsou pro vysokou míru dominance učitele v kombinaci s vysokou mírou vřelosti (Šed'ová, 2015). Naproti tomu je tendence k odklonu od dominance učitele. Wubbels a Brekelmans (2005) upozorňují na to, že účinky blízkosti jsou silnější než účinky vlivu. Šed'ová (2015) ve své případové studii věnující se mocenským vztahům mezi učitelem a žáky v dialogickém vyučování ukazuje, že je produktivní utlumení dominance učitele, a analyzuje, jak ho učitelé dosahují (rozpuštění dominance, sjednocování definice situace). I my se přikláníme k tezím, že k tomu, aby mohl třídní učitel navázat vztah se svými žáky, je do jisté míry nutné utlumit jeho dominanci vůči žákům. V této souvislosti souhlasíme s Pelikánem (2002), který zdůrazňuje, že je důležité, aby se žák a učitel vnímali jako blízcí lidé.

\section{Metodologie}

$\mathrm{V}$ tomto textu si klademe za cíl analyzovat determinanty dobrého vztahu mezi třídní učitelkou a jejími žáky. Pro tento článek koncentrujeme svoji pozornost pouze na osobu třídní učitelky. Chceme se zaměřit na její osobnostní charakteristiky a z nich vycházející interpersonální chování vůči žákủm. Výzkumná otázka zní: Jaké osobnostní charakteristiky a jaký typ interpersonálního chování třídní učitelky determinují dobrý vztah s žáky její třídy?

Data pro tuto studii byla získána v rámci př́ípadové studie jedné tř́ídy s dobrým sociálním klimatem na střední odborné škole. Zatímco tato studie koncentruje svoji výzkumnou pozornost na třídní učitelku, disertační práce, jejíž je př́ípadová studie součástí, se zaměřuje na všechny aktéry ve třídě (tj. jak tř́́dní učitelku, tak na všechny žáky). Zdrojem dat jsou rozhovory se žáky a třídní učitelkou a pozorování v hodinách první pomoci vedených tř̌́dní učitelkou. Výzkum probíhal ve středoškolské tříděškoly bezpečnostně-právního zaměření s dobrým sociálním klimatem, kterou jsme vybrali prostřednictvím kvantitativního šetření ve 24 třídách středních škol s bezpečnostně-právním zaměřením² pomocí dotazníku Klima školní třídy (Mareš \& Ježek, 2012). Kritériem pro volbu případu byly vysoce nadprůměrné výsledky $\mathrm{v}$ tomto dotazníku v rámci tříd, které se šetření účastnily (podrobněji viz Bendová,

2 Jednalo se vždy o čtyřleté střední odborné školy s maturitou bezpečnostně-právního zaměření. Zastoupeny byly kraje Jihomoravský, Zlínský, Moravskoslezský, Královéhradecký a Plzeňský. 
2012, 2013). ${ }^{3}$ Sběr dat pomocí dotazníku probíhal v druhém pololetí školního roku 2011/2012, kdy zkoumaná třída byla ve třetím ročníku. Po celý následující školní rok, ${ }^{4}$ tj. 2012/2013, probíhal sběr dat prostřednictvím polostrukturovaných rozhovorů a zúčastněného pozorování v hodinách první pomoci, které vedla třídní učitelka Iva. Scénář polostrukturovaných rozhovorů vycházel z položek v dotazníku (cílem bylo ověřit a prohloubit informace z dotazníků a získat informace nové) a byl zaměřen hlavně na psychosociální klima třídy. Celkem proběhlo 24 rozhovorů s žáky (podrobněji viz Bendová, 2013). Ve stejném rozsahu proběhl i rozhovor s učitelkou. Mimoto probíhaly po celý školní rok podle potřeby dílčí rozhovory s učitelkou, související s pozorováním ve třídě. Jeden z rozhovorů proběhl také poté, co žáci ukončili studium. Rozhovory s jednotlivými aktéry i pozorování ve tř́́dě byly nahrávány na diktafon. Za celý školní rok jsme shromáždili rozsáhlý korpus dat. Získaná data byla analyzována pomocí otevřeného kódování a podrobena triangulaci. Vzniklé kódy jsme dále kategorizovali.

Impulzem pro studii samostatně zaměřenou na osobu třídní učitelky byla její extrémní obliba u žáků, která byla patrná již po kvantitativní části výzkumu. Nadstandardní vztah mezi učitelkou a žáky byl dále potvrzen kvalitativním šetřením. Zkoumanou třídní učitelkou se stala 49letá učitelka s aprobací pro biologii a tělesnou výchovu na střední škole s 15letou praxí. Učitelka je oblíbená nejen mezi žáky, ale také svými kolegy. Důvodem jsou její komunikační kompetence, vstřícnost, ochota pomoci, smysl pro humor a také odbornost. Prosociálnost prezentuje i při mimoškolní aktivitě, při níž se svým kolegou a s vybranou třídou každoročně spolupracuje s domovem pro seniory. Zkoumaná třída je její třetí, ve které působí jako třídní učitelka. Podle jejích slov načerpala z předchozího třídnictví dostatek zkušeností, jež jí pomohly při vedení této třídy. $\mathrm{V}$ době, kdy tato třída byla ve čtvrtém ročníku, bylo jejím dětem (synovi a dceři) 21 a 19 let a to, jak se ukázalo, sehrálo ve vztahu k žákům také roli. V položkách (týkajících se učitele) dotazníku Klima školní tř́́dy (Mareš \& Ježek, 2012) dosáhla velmi vysokého percentilového skóre. To potom koresponduje se zjištěními v kvalitativním šetření. Žáci o své třídní učitelce mluví rádi a většinou v superlativech. („Úžasná třídní, lepšího člověka jsem jak po osobní, tak po pedagogické stránce nepoznala..." Nebo: „Je suprová, bombastická, nejlepší třídní, kterou můžeme mít. Vyslechne, pochopí vše a pomůže," apod.)

3 Podle „norem“ dotazníku Klima školní tř́ídy (Mareš \& Ježek, 2012) dosahuje škála Vnímaná opora od učitele 95. percentil.

4 Třída byla ve čtvrtém ročníku, proto zúčastněné pozorování bylo ukončeno již v dubnu 2013. Dílčí rozhovory s učitelkou Ivou probíhaly i poté. 


\section{$3 \quad$ Výsledky}

3.1 Osobnostní prededpoklady učitelky k budování optimálního vztahu se žáky V osobnostní výbavě učitelky Ivy jsme identifikovali tři charakteristiky, které se podle našeho názoru nejvýznamněji podílejí na budování dobrého vztahu s jejími žáky.

\section{Mateřská starostlivost a vřelost}

Domníváme se, že osobnostní charakteristikou učitelky Ivy, která je klíčem k dobrému vztahu s žáky, je citová vřelost a starostlivost o žáky. Je zmiňována všemi žáky a také zřetelná v pozorovatelném chování. To je potom patrné zejména prostřednictvím expresivních reakcí žáků (viz níže). Většina žáků charakterizuje učitelku podobným způsobem: „Je hodná, je taková hodně, dá se říct, že se snaží dělat první poslední a tak, prostě taková maminkovská." I přesto, že se jedná o dospělé žáky čtvrtého ročníku střední školy, je právě tato starostlivost tím, co považují u své třídní učitelky za to nejdůležitější, co nejvíce ovlivňuje jejich vzájemný vztah. Mnoho žáků dokonce přiznává, že jim učitelka „supluje“ rodiče:

„No je to blbý, ale ona se o mě stará víc jak naši. No ne, že bych je nezajímal, ale mamka už má s př́telem malého, tak se spíš starají o něho, a s tat'kou se vidím jednou za čas. Ještě horší je to ted', když jsem na intru." (žák Jarek)

Tento výrok potom dokládá i sama třídní učitelka: „... občas jsem měla pocit, že jim supluju maminku..." Učitelka Iva se snaží svůj nadstandardní zájem o pochopení žáků vysvětlit: „Jestli to nebude tím, že mám stejně staré děcka. To asi hraje roli..."

\section{Extroverze a zdravé sebevědomí}

K nejtypičtějším charakteristikám učitelky Ivy patří její extroverze. Ta má vliv na kompetenci komunikovat nejen s žáky, ale i s učiteli. Extroverze v jejím pojetí se projevuje i velkou angažovaností. Žák Marek vtipně poznamenává: „Ona vždycky než přijde o přestávce do kabinetu, to je hrozný, zastaví se ještě cestou s deseti lidmi, ale to je prostě ona." Jiná žákyně charakterizuje její extroverzi takto:

„No mluví rychle, všechno ví, co se kde šustne. Ale je fakt, že my máme taky všechno z první ruky..." (žákyně Tamara) 
Učitelka Iva má zájem o dění, ráda se angažuje, žáci ji často nazývají „akční“. Vzhledem ke svému temperamentu nemá problém konverzovat jak s žáky, tak s učiteli. Je proto vždy velmi kompetentní v poskytování informací i v běžné neformální komunikaci. S extroverzí také souvisí její sebevědomí. Je si vědoma svého vlivu i schopnosti přesvědčit a zaujmout žáky: „Já už vím, jak na ně." Potvrzuje tak požadavek vysokého sebevědomí pro sociálně a emočně kompetentní učitele (Jennings \& Greenberg, 2009).

\section{Životní zkušenosti versus mladistvost}

Jako jeden z důvodů dobrého vztahu s žáky v její roli třídního učitele udává učitelka zkušenosti s třídnictvím: „Už to je moje třetí třída. Já už nad tím mám takový jakýsi nadhled nebo větší zkušenosti jako třídní. Už mě daleko míň věcí rozhází. Víc vím, jak na ně." Z uvedeného výroku je patrné, že zkušenosti považuje za zdroj svého kompetentního vedení třídy. Lze předpokládat, že se z minulých chyb poučila a zkušenosti zúročila při vedení této třídy. Žáky je ale také pozitivně vnímána mladistvost v projevu se zájmem o svět, ale i o sebe sama (např.: „Takhle bych chtěla vypadat v jejím věku.“). 0 svůj vzhled zjevně pečuje. Obléká se velmi atraktivně a barevně ve srovnání se svými vrstevnicemi (např:: „Oblíká se fakt dost dobře, my jí přezdíváme módní ikona."). Kromě toho se na jejím vzhledu projevuje kladný vztah ke sportu. To oceňuje jeden žáků: „Je na ni docela př́ijemný pohled, je vidět, že sportuje.“ (žák Marek). Z výroků žáků je patrné, že vzhled učitelky u žáků hraje roli a že jsou na svoji učitelku v tomto ohledu pyšní. Domníváme se, že ve vnímání učitele žákem hraje vzhled učitele velmi významnou roli.

\subsection{Interpersonální chování třídní učitelky}

Jde o chování vyplývající z uvedených osobnostních charakteristik učitelky Ivy. Jedná se o běžnou interakci a komunikaci spjatou nejčastěji s výukou nebo řešením třídnických záležitostí přispívající k dobrému vztahu s žáky nebo o interpersonální chování, které přímo vyjadřuje vztah k žákủm.

Běžná interakce a komunikace spjatá predevším s výukou

Expresivnost komunikace

Komunikace učitelky Ivy se vyznačuje velkou mírou expresivity. To její komunikaci odlišuje od komunikace jiných učitelů v hodinách i mimo ně. Gavora (2005, s. 95) mluví v této souvislosti o tom, že komunikace učitelů je často 
věcná, chladná. Učitelka Iva naopak dává emoce prostřednictvím paralingvistických prostředků velmi často najevo. Tento způsob je pro ni velmi typický. Ještě výrazněji se expresivnost projeví např. při apelování na žáky, zprostředkovávání emocí apod. $Z$ terénních poznámek vyplývá, že ve třídě bylo při následujícím monologu absolutní ticho:

No vážně, začněte být trochu víc samostatní. My se tady o vás vážně až moc staráme. Zatím ani nezvládnete mít dostatečně prázdnou mailovou schránku, aby vám mohly chodit maily z CERMATU. Každý rok je s tím problém. Ted’ už to bude pořád jen a jen na vás. Na vysoké škole vás nebude vodit nikdo za ručičku.

Expresivnost bývá často patrná i při zprostředkování výkladu. Témata předmětu první pomoc umožňovala žákům spoluprožití krizových situací:

A ti lidi mají reálně strach o svůj život. Statisticky je prokázáno, že když má někdo zdravotní problém, i třeba rakovinu, nevnímá to tak intenzivně jako obavu o svůj život, jako ti, co mají onemocnění srdce.

Třídní učitelka Iva dále velmi často $v$ běžných situacích využívá zdrobněliny. Zdrobněliny užívá u jmen i v běžné komunikaci nebo výkladu (např:: „Další otázka je lehounká." nebo „Nožky mu zvedneme."). Zvlášt' patrná je expresivnost při vyjadřování empatie k žákủm. Zde opět hraje kromě řečeného obsahu velkou roli tón hlasu a neverbální projevy (např.: „Já ti, Kubo, rozumím, já to měla podobně, au, au." nebo „Děcka, nesmějte se mu. To je vážně hrozné. Nikomu to nepřeju.").

Podněcování k aktivitě, poučování aneb klasická role učitele

Vzhledem $\mathrm{k}$ tomu, že sběr dat probíhal zejména ve třídě při běžné výuce předmětu první pomoc, nelze opomenout, jakým způsobem vede učitelka výuku. Ve výuce klade velký důraz na motivaci žáků. Tato motivace bývá obvykle velmi expresivní. K motivaci užívá učitelka povzbuzování, jímž se snaží zvrátit jejich pochyby o vlastních vědomostech a schopnostech. V situacích, kdy žáci pochybují o svých schopnostech zachránit někomu život, učitelka podotýká: „No jasně, nemůžete pomoct všem, ale určité vědomosti už máte. A taky jste odvážní sportovci, určitě se do toho vrhnete víc po hlavě než člověk z davu."

Stejným způsobem je motivuje k přemýšlení: „Děcka, přemýšlejte, to víte, už jsme si to říkali a od vás už jsem to taky slyšela." Při motivaci žáků učitelka Iva 
užívá často i direktivní tón: „Zítra se pořádně vyškolíte a budete dávat pozor. My tam budeme." Svým slovům dává důraz zvýšením hlasu. Vzhledem k jejímu spíše neformálnímu výkladu tímto tónem vzbuzuje pozornost, a i když je její hlas silný i při běžné komunikaci, tady ještě na síle přidává. Pokud má možnost, žádá o potvrzení svých slov žáky: „Ve středu o půl dvanácté budeme mít přednášku toho hasiče. Vítek ho zná, takže vám může potvrdit, že bude stát za to, abyste tu byli a poslouchali ho."

Při poučování žáků vystupuje Iva v roli autority:

U: Nikdo neví? Tak oni mají předepsané nějaké léky, nitroglycerin mají většinou s sebou a jsou schopni nám říct, mám ho v šuplíku nebo v kapse, a sami si ho musí dát, nikdy těm lidem nesmíte nic cpát! Co se může ještě dávat, prosím vás? Která tabletka, už jsem to ř́kala včera.

Žák Karel: Paralen?

U: Paralen ne, ten neředí krev, když nevíte, dejte mu cucat acylpyrin, tím nic nezkazíte.

Je patrné, že učitelka je odborníkem ve svém oboru, kterým je biologie. $\mathrm{V}$ tomto směru vystupuje velmi suverénně. Tímto a také tím, že se snaží žákům zodpovědět každou jejich otázku, budí u žáků respekt. Velmi často se žáci na učitelku obracejí s žádostí o vysvětlení něčeho, co souvisí s tématem. („Paní učitelko, jo, to se mi stalo jednou u dvanáctiminutovky, ${ }^{5}$ co to bylo?“)

Neformální vedení výuky

Komunikace $\mathrm{v}$ této třídě se často vyznačuje velkou neformálností jednotlivých aktérů. Př́́kladem je situace, kdy před koncem hodiny do tř́dy vchází žákyně, která byla u lékaře: „Jéé, Lad'ko, ty už jsi tady, jak jsi s tím kolenem dopadla, pojd' nám to honem říct." Uvedený výrok je příkladem, kdy učitelka neformální komunikací vyjadřuje zájem o žáky, zainteresovanost na jejich problémech.

Způsob komunikace ve třídě vytváří typicky zvýšenou hladinu šumu. Učitelka Iva akceptuje poměrně silnou hladinu ruchu i nad rámec výuky. Vzhledem k našim zjištěním souhlasíme s výzkumem Tobina a kol. (2013), kteří zjistili, že ruch ve třídě (collective effervescence) může v určitých situacích přispět k pozitivnímu emočnímu klimatu. Kontrastem k vyšší hladině ruchu jsou již

5 Dvanáctiminutový běh neboli Cooperův test je test fyzické zdatnosti jedince. 
zmíněné velmi expresivní monology učitelky, při nichž naopak šum úplně ustává a ve tř́ídě bývá naprosté ticho. Tyto dva póly jsou pro atmosféru v její třídě charakteristické. Pokud však žák překročí učitelkou vytyčené hranice, funguje i zde to, co Šed'ová (2015) nazývá záchrannou brzdou. Pokud žák podle ní narušuje výuku, požádá jej, aby od jednání upustil: „Pepo, prosím, abys nehovořil nebo hovořil k tématu." Jen ve velmi výjimečných případech je schopna sáhnout po „tradičních“ kázeňských opatřeních: „Karin, mohla bys, prosím tě, odejít ze třídy?"

Rysem komunikačních kompetencí je schopnost vyprávět a vypointovat př́běhy. Tuto schopnost má i učitelka Iva. Žákům vypráví příběhy velmi často, jak při běžné komunikaci, tak při výuce. Tím je její výuka typická. To zároveň znamená, že částečně nebo úplně odbočí od tématu hodiny.

Žáci často na její vyprávění reagují a monolog se mění v dialog:

U: Já si ještě vzpomínám, když jsme byli ještě na škole někdy v prváku na Chopku, někdy v březnu, tam je to docela vysoko. A tam teda polovina děcek, polovina bab měla úplně napuchlé oči, do druhého dne dostaly těžký zánět spojivek. Neměly pořádné brýle. Tehdy nebylo lehké mít pořádné brýle. Tehdy nebylo lehké mít pořádného nic.

Žák Václav: Jak to myslíte, paní učitelko?

U: To jsem si jen „nostalgicky“ vzpomněla na ty časy za totality. Když mi bylo jako vám, tak byl ještě socialismus, i když už na spadnutí...

Žák Václav: Tak to muselo být dost děs.

Pro komunikaci $v$ této třídě je velmi typický humor učitelky a žáků. Ten zde, stejně jako v jiných skupinách, zprostředkovává radost, dodává energii, pomáhá zvládat nepř́ijemné situace atd. (srov. Šedová, 2013). Domníváme se, že velký význam má i to, že učitelku její třída „baví“ a vnímá své žáky jako vtipné. Učitelka sdílí i humor svých žáků a vyhledává jejich přítomnost i mimo běžnou výuku: „To s něma je totiž hrozná švanda. Já si do té třídy chodím normálně odpočinout. Já, i když mám přestávku, si tam chodím sednout k nim do třídy." Lze předpokládat, že se učitelka cítí v přítomnosti žáků dobře a uvolněně. $Z$ výsledků analýzy zúčastněného pozorování vyplývá, že i učitelka je často iniciátorem humoru. Lehký nádech černého humoru je př́itomen i v běžném výkladu učební látky v hodinách první pomoci, funguje tu jako jakýsi protipól vážnějších expresivních vyjádření učitelky. V podstatě je 
funkcí tohoto typu humoru vyrovnat se s nějakým závažným tématem („Když ty krvácející tepny na krku zaškrtíte obě, tak to má za pár."). Následující ukázka představuje humorné vyprávění, na které žáci reagují.

U: Tak to je Bürgerova choroba. To jeden, uřízli mu ruku, nohu... Jeho spolubydlící v nemocnici mu vyrobili protézu, aby mohl kouřit dál.“ (ŽŽ: smích)

Tak to je fakt drsný... (někdo $v$ šumu)

Žáci se obecně rádi smějí sobě navzájem a rádi se smějí učitelům, raději než jejich vtipům (viz Šed'ová, 2013). V této třídě platí první teze, neplatí však ta druhá. Ačkoliv si (nebo právě proto) nemá učitelka problém udělat legraci sama ze sebe (např:: „... to jsem to zas s tím počítačem vymňoukla, děcka, pomooc!"), nezaznamenali jsme žádnou situaci, kdy by si žáci ze své učitelky „utahovali“.

\section{Interpersonální chování vyjadřující vztah $k$ žákům}

Chápeme ho jako chování učitelky, ze kterého je zřejmá podoba vztahu k žákům. Toto chování je pro žáky snadno srozumitelné a je vyjádřeno konkrétními činy učitelky. Podle našeho názoru se toto interpersonální chování nejvíce váže k osobě tř́dního učitele a také je hlavní determinantou dobrého vztahu mezi učitelkou a žáky.

\section{Péče a podpora}

Nejcharakterističtějším vyjádřením vztahu k žákům je péče o žáky. Pro učitelku Ivu je typické, že tu není jen pro třídu, ale hlavně pro jednotlivce. Žáci vědí, že se na ni mohou s důvěrou obrátit, a ona je ochotna jim pomoci: „Vidím, že se o nás opravdu zajímá, a je na ní vidět, že nám chce pomoci, prostě se ptá, jak to dopadlo, jestli ještě něco nepotřebuju." (žákyně Ivona). Žáci často zdůrazňují, že ke každému přistupuje stejně (napřs: „Nedělá mezi náma rozdíl.“). Když žáci této třídy mluví o vztahu s učitelkou, často popisují vzájemný vztah jako párový. Pokud mluví o aspektech tohoto vztahu, zmiňují ochotu učitele jim pomoci a neoddělování školních a soukromých věcí od sebe:

Já jsem nezažil nějaký problém, se kterým bych za ní nemohl přijít a vyřešit to s ní, cokoliv se mi stalo nebo když jsem měl problémy v rodině, se vším mi pomáhala. To stejné, když jsem měl problém ve škole, tak vše jsem řešil hlavně s tř́́dní. (žák Vladan) 
Žáci většinou připojí nějaký konkrétní případ, situaci, kdy jim byla učitelka nápomocna (např.: „Když bylo u nás doma dusno, tak mi pomohlo jen si s ní o tom popovídat."). Třídní učitelka se snaží naslouchat a pochopit problémy žáků. Ti si velmi cení její přátelské a vstř́ícné komunikace: „Protože naše tř́́dní je člověk, který dokáže pochopit snad úplně všecko, ona mluví s námi na naší úrovni, ví, jak s námi mluvit." (žákyně Nad'a). Žáci si hlavně cení toho, že jim učitelka aktivně naslouchá, vědí, že nemusí mít obavu z toho, že by jejich problémy zlehčovala nebo je nepochopila. Nemají z jejího jednání také pocit, že by někoho preferovala, naopak vyslechne a pomůže každému se stejnou ochotou. Výstižně ji často žáci přirovnávají k matce, která má ráda všechny bez rozdílu: „Ona je taková hodná, ochotná vždycky pomoct, všem pomůže, bere nás jako svoje děti." (žákyně Tamara).

Otevřené vyjadřování emocí učitelkou

Uvedené charakteristiky učitelky Ivy, jako je extroverze, expresivnost (viz výše), se projevují velmi otevřeným vyjadřováním emocí. To je v českém prostředí u učitelů neobvyklé. Gavora (2005) upozorňuje na to, že se učitelé bojí, že pokud se otevřou, ztrácí část svojí autority. Zároveň však dodává, že schopní učitelé dokážou efektivně používat svoji autoritu a být k žákům milí (Gavora, 2005, s. 95). Žáci této třídy si na učitelce cení toho, že se emoce nebojí projevovat:

Ona to totiž vždycky řekne naplno, když jsme ji potěšili, tak z nás měla radost jak malý děcko. Ale i když je naštvaná, tak to prostě taky řekne, ale tak taktně, nikdy na nás neřvala, tak jsme to vždycky vzali. (žák Matouš)

Sama učitelka Iva v rozhovorech neskrývá velmi pozitivní vztah ke své třídě a ani to, že jej dává žákům vždy najevo:

Já bych řekla, že je mám ráda. A oni vědí, že je mám ráda. $V$ důsledku toho mě nechtějí naštvat. A vidí, že se mnou nemají žádný konflikt. A to je hodně tím, že si vždy vše hned řekneme, jak to je. A to je pak asi docela př́ijemný vztah.

Z výroku učitelky je patrné, že ke kvalitnímu vztahu mezi ní a jejími žáky přispívá i otevřené vyjadřování emocí. Žáci vždy přesně vědí, co učitelka cítí, co ji potěšilo, i to, co ji naštvalo. Na základě tohoto, že žáci pocit’ují lásku učitelky, a toho, že jedná „na rovinu“, se daří možné problémy řešit včas a eliminovat vzájemné konflikty. 
Naslouchání a sdílení osobních informací

Vzhledem k učitelčině „povaze“ mají žáci její třídy nejen všechny důležité informace, které potřebují ke studiu, ale také informace o dění ve škole, mimo ni a částečně z učitelčina soukromí (např:: „Já jim vždycky vyprávím, co ta moje dcera, co ten můj syn. No a víš, jak říkají tomu mému muži? Paní Colombová, že jako o něm pořád mluvím, ale ještě ho nikdo nikdy neviděl.“). Vzhledem k tomu jí recipročně také informace sdělují. Další související kompetencí učitelky je schopnost naslouchat žákům a nevnucovat jim svůj názor: „Prostě jakoby umí celkově naslouchat tomu druhému a používat to, co ten druhý vlastně řekne a neprosazuje jen ten svůj názor, za kterým si prostě jde." (žák Petr). Žáci potvrzují, že se učitelce často svěřují nejen se svými problémy, ale i s běžnými záležitostmi (např:: „Ona je totiž taková vrba, všechno vyslechne, i když jsou to takové naše kecy."). Tuto její schopnost vyzvedávají při srovnání s učiteli, ke kterým nemají tak kladný vztah.

Pro učitelku Ivu je důležité znát problémy žáků, ale i informace z jejich osobního života. Učitelka Iva vede monolog o tom, kdy jí žáci nejčastěji sdělují osobní informace:

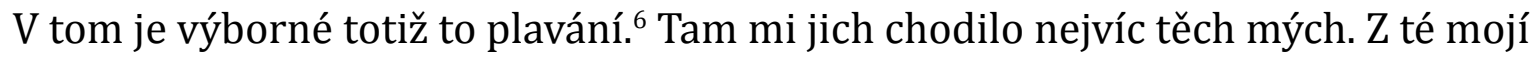
třídy. A oni vykládají úplně všechno (smích). To plavání je asi takové dobré. No a potom na těch kurzech. ${ }^{7}$ A pak ty naše společné akce.

Učitelka přiznává, že nejvíce komunikuje $s$ žáky mimo běžnou výuku. Ukazatelem dobrého vztahu mezi učitelkou a žáky je to, že bývá čestným hostem na akcích, které žáci její třídy pořádají mimo školu (např:: „Oni, když si jdou někam odpoledne sednout, tak mě často zvou. Když mám čas a není to moc večer, tak se tam stavím."). Implicitně učitelka potvrzuje také názor, že přímo ve školním procesu, v běžné hodině nelze žáka spolehlivě poznat.

\section{Uplatňování vlivu}

Učitelka Iva si je vědoma velkého vlivu na žáky a snaží se jej v plné míře uplatňovat. Snaží se primárně působit na jednotlivé žáky, a tím je do určité míry i vychovávat. To se děje především při řešení jejich osobních i školních problémů. V souvislosti s ovlivňováním žáků je učitelka zmiňována nejčastěji.

\footnotetext{
Nepovinný předmět.

7 Kurzy (např. horolezecký, střelecký apod.) probíhají na této škole pravidelně od 1. ročníku $1-2 x \mathrm{v}$ jednom školním roce.
} 
Její vliv vztahují žáci nejčastěji ke své vlastní osobě a v některých situacích ovlivňuje i rozhodování v osobních nebo rodinných záležitostech: „Má na mě největší vliv na této škole. Prostě když jsem blbla v prváku a chtěla odejít, tak si se mou sedla a všechno to se mnou probrala. Asi měla největší vliv na to, že jsem pak zůstala." (žákyně Ivona)

Žáci si také velmi cení toho, že učitelka řeší privátně s jednotlivci, nikoliv veřejně před třídou, i kázeňské a prospěchové problémy žáků:

Když se špatně chováme nebo máme špatný známky, tak to neprobírá mezi všema, prostě si nás vezme bokem a ptá se, co blbnem, jestli něco doma, a snaží se na nás nějak zapůsobit, většinou se pak nějak vybičujem a zlepšíme se. (žák Hynek)

Reakcí na takový rozhovor mezi žákem (žákyní) a učitelkou je potom snaha s problémem něco dělat („nějak se vybičujeme“). Pokládáme za důležité i to, že učitelka v těchto situacích neuplatňuje nad žáky svoji moc, ale snaží se je motivovat k lepším výkonům. Svá očekávání se snaží jasně formulovat. Tuto „přesvědčovací strategii“ charakterizuje jeden žák takto: „Ona nás pořád $\mathrm{k}$ něčemu tlačí. Teda myslím to $\mathrm{v}$ dobrém slova smyslu." (žák Vít).

Žáci chápou učitelku jako právoplatného člena kolektivu:

Myslím, že do kolektivu dost přidala, třeba když jsme se hádali ve druháku, tak se snažila... Jako at' toho necháme být, at' se nedohadujeme, že se snažila do toho nějak zasáhnout, jako že jsme to potom nějak urovnali. (žákyně Nela)

Vystupuje jako autorita, která se snaží žáky přesvědčit. Velký vliv na třídu má právě tehdy, když jedná s žáky jako s dospělými: „A když jsme $s$ ní jeli na dva dny do Prahy, jednala s námi jako s dospělákama, že už je to naše zodpovědnost a že nám věří. No a tak to každej vzal a proběhlo to úplně v klidu." (žák Vít).

Zde je vidět, že učitelka dává žákům důvěru a zdůrazňuje odpovědnost každého za sebe sama. Reakcí žáků je potom snaha tuto projevenou důvěru nezklamat. To je samozřejmě ve vazbě na vztah, který k ní žáci mají, jak již bylo zmíněno výše. Podobně je tomu v následující situaci, v níž se ještě přidává tendence žáků svěřovat svojí učitelce informace o mimoškolních aktivitách a akcích, kterých se žáci společně účastní: 
Když je nějaká třídní párty, tak o tom třídní ví, řekne nám, at’ se chováme, jak máme, a at' zítra přijdeme do školy. No a nám je pak fakt docela blbý tam nepřijít, když to ona ví. A třeba bych se ani moc neopil, aby to pak druhý den bylo vidět a ona si řekla, že jsme fakt blbci. A tak to mají asi všichni. (žák Robin)

Žáci učitelce naprosto důvěřují, proto mají jistotu, že soukromé informace, které jí sdělují, nebudou ve školním prostředí zneužity. Když má učitelka tendenci nějak zasáhnout do mimoškolních akcí, nedělá to z pozice učitele, ale snaží se opět pozitivně motivovat, působit na citovou stránku jejich osobnosti. V této formě jsou žáci schopni si vzít její rady k srdci. Žáci se cítí objektem učitelčina působení nejen při řešení různých problémů, ale i v běžných situacích, při přátelských rozhovorech. „Ona tu tř́du ovlivní, i když si tam přijde jen tak o přestávce pokecat, co prostě nového, jak se máme. Často se při té př́ležitosti dozvím něco i o jiných lidech z naší školy." (žákyně Alena). Z uvedeného výroku dále vyplývá, že utužuje kolektiv pravidelnou neformální komunikací mimo výuku, při které žáci občas jako „bonus“ získávají nějakou zajímavou informaci.

\section{Diskuse a závěr}

V tomto článku nás zajímalo, co z hlediska třídního učitele determinuje jeho dobrý vztah s žáky. Identifikovali jsme osobnostní předpoklady učitelky k budování optimálního vztahu s žáky a interpersonální chování učitele, které k dobrému vztahu přispívá. Z hlediska expertnosti třídního učitele jsme se zaměřili hlavně na osobnostní, nikoliv profesní složku. ${ }^{8}$

Výsledky př́padové studie ukázaly, že mezi osobnostními rysy učitelky dominuje vřelost a „mateřská“ starostlivost o žáky. To je vlastnost, kterou žáci u své učitelky nejvíce vyzdvihují. Naše data korespondují s výzkumy, které dokazují, že učitelova vřelost a citlivost přispívají ke zdravým vztahům ve tř́idě (např. Anderson 1982; Pianta et al., 2002 aj.). Zároveň učitelka vykazuje vysokou míru dominance (extroverze) a zdravého sebevědomí, to je podporováno životními i pedagogickými zkušenostmi a mladistvým přístupem a vzhledem. Splňuje tímto částečně i požadavek kombinace vřelosti s vysokou dávkou dominance (Wubbels \& Brekelmans, 2005). Na druhou stranu je podle našeho názoru velmi významné, že svoji dominanci dokáže vhodně utlumit. Mocenské konstelace mezi učitelkou a žáky tedy nejvíce odpovídají

8 Přesto, že odbornost nebyla předmětem našeho zájmu, z výsledků vyplynulo, že učitelka je i velkým odborníkem ve svém oboru. 
typu, jejž Šed’ová (2015) nazývá cirkulací moci. To znamená, že učitel slevuje ze své dominance a moc je rozptýlena mezi něj a žáky. Je zde také výrazně překračována tradiční role učitele směrem k potlačení asymetrie ve vztazích mezi učitelkou a žáky (viz Pelikán, 2002). Běžně v hodinách se tak děje hlavně prostřednictvím neformální komunikace, humoru a vyprávění příběhů. Její komunikace je typická expresivností (její hlas vždy jasně signalizuje emoce). Tradiční role učitele je dále překračována prostřednictvím čtyř dimenzí interpersonálního chování, které vyjadřuje vztah k žákům: (1) péčí a podporou žáků, (2) otevřeným vyjadřováním emocí učitelky, (3) nasloucháním žákům a sdílením osobních informací, (4) uplatňováním vlivu se snahou žáky „vychovávat". Toto charakteristické interpersonální chování má podle našeho názoru klíčový vliv na podobu vztahu třídní učitelky a žákủ. Domníváme se, že tyto dimenze interpersonálního chování učitelky Ivy nejvíce naplňují pojem expertnost trídního učitele v sociálních vztazích se svými žáky.

Přesto, že jsme považovali za zajímavé zacílit pozornost na třídní učitelku s výjimečným vztahem se žáky, uvědomujeme si, že nejzásadnějším limitujícím faktorem této studie je právě to, že byla užita data týkající se pouze jednoho učitele. Kromě obecných limitů kvalitativního výzkumu se tedy přidává fakt, že se jedná pouze o jediný případ. Ten může však být inspirací pro další podobná zkoumání.

Při prezentaci uvedených výsledků je dále třeba upozornit, že se jednalo nejen o výjimečnou učitelku, ale i o tř́du s velmi dobrým sociálním klimatem. Z výzkumu vyplývá, že pro vzájemný vztah mezi aktéry v této třídě jsou klíčové nejen charakteristiky a interpersonální chování učitelky, ale i charakteristiky a interpersonální chování žáků (viz Bendová, 2013). Sama učitelka upozorňuje na výjimečnost třídy a podotýká, že nikdy „tak dobré děti ve třídě neměla“. Dále pokračuje: „... tuhle třídu hodnotím určitě nejlíp... Ale nemůžu ř́íct proč. To nebylo ani o nějakých jednotlivých dětech. Ale oni fakt... Já mám pocit, že se měli mezi sebou hrozně rádi, no raději než ty předešlé tř́dy..." Data týkající se žáků to potvrzují. V souvislosti s tímto se nabízí otázka podmínek pro plný rozvoj expertnosti.

\section{Literatura}

Bendová, A. (2012). Klima tříd na středních odborných školách s bezpečnostně právním zaměřením: výsledky dotazníkového šetření. In T. Janík \& K. Pešková (Eds.), Školní vzdělávání: podmínky, kurikulum, aktéři, procesy, výsledky (s. 33-46). Brno: Masarykova univerzita. 
Bendová, A. (2013). Charakteristiky oblíbeného učitele a třídy s dobrým sociálním klimatem: návrh kategoriálního systému. In T. Janík \& K. Pešková (Eds.), Školní vzdělávání: od podmínek $k$ výsledkům (s. 224-237). Brno: Masarykova univerzita.

Blížkovský, B. (1966). Příručka třídního učitele. Praha: SPN.

Čáp, J., \& Mareš, J. (2001). Psychologie pro učitele. Praha: Portál.

den Brok, P. J., Brekelmans, J. M. G., Levy, J., \& Wubbels, T. (2002). Diagnosing and improving the quality of teachers' interpersonal behaviour. International Journal of Educational Management, 16(4), 176-184.

Fisher, D., den Brok, P., \& Rickards, T. (2006) Factors influencing students' perceptions of their teachers' interpersonal behavior: A multilevel analysis. In D. Fisher \& M. S. Khine (Eds.), Contemporary approaches to research on learning environments: Worldviews (s. 51-74). Singapore: World scientific publishing.

Gavora, P. (2005). Učitel a žáci v komunikaci. Brno: Paido.

Helus, Z. (2001). Alternativní pohled na kompetence učitelů. In E. Walterová (Ed.), Učitelé jako profesní skupina, jejich vzdělávání a podpůrný systém (s. 44-49). Praha: Univerzita Karlova v Praze.

Jacob, B. A., Kane, T. J., Rockoff, J. E., \& Staiger, D. O. (2009). Can you recognize an effective teacher when you recruit one? Ann Arbor: University of Michigan.

Jennings, P. A., \& Greenberg, M. T. (2009). The prosocial classroom: Teacher social and emotional competence in relation to student and classroom outcomes. Review of Educational Research, 79(1), 491-525.

Khine, M. S., \& Lourdusamy, A. (2006). Reflective analysis of teachers' behaviour and students' perception of classroom interaction. In D. L. Fisher \& M. S. Khine (Eds.), Contemporary approaches to research on learning environments (s. 29-50). London: Worldviews.

Korthagen, F. A. (2004). In search of the essence of a good teacher: Towards a more holistic approach in teacher education. Teaching and Teacher Education, 20(1), 77-97.

Korthagen, F., \& Vasalos, A. (2005). Levels in reflection: Core reflection as a means to enhance professional growth. Teachers and Teaching, 11(1), 47-71.

Leary, T. (1957). Interpersonal diagnosis of personality; a functional theory and methodology for personality evaluation. New York: Ronald press company.

Loudová, I. (2012). Kompetence tř́́dního učitele k péči o kvalitu života žáků (Disertační práce). Brno: Masarykova univerzita.

Mareš J., \& Ježek S. (2012). Klima školní třídy: dotazník pro žáky. Praha: Národní ústav pro vzdělávání.

Pelikán, J. (2002). Pomáhat být: otevřené otázky teorie provázející výchovy. Praha: Karolinum.

Pianta, R. C., La Paro, K. M., Payne, C., Cox, M. J., \& Bradley, R. (2002). The relation of kindergarten classroom environment to teacher, family, and school characteristics and child outcomes. Elementary School Journal, 102(3), 225-238.

Píšová, M., Najvar, P., Janík, T., Hanušová, S., Kostková, K., Janíková, V., \& Zerzová, J. (2011). Teorie a výzkum expertnosti v učitelské profesi. Brno: Masarykova univerzita.

Spilková, V. (2001). Profesní standard a klíčové kompetence učitele primární školy. In E. Walterová (Ed.), Učitelé jako profesní skupina, jejich vzdělávání a podpůrný systém. Sborník z celostátní konference (s. 89-95). Praha: Univerzita Karlova v Praze. 
Spilková, V., \& Vašutová, J. (2008). Učitelská profese v měnících se požadavcích na vzdělávání. Praha: Univerzita Karlova v Praze.

Spousta, V. (1993). Základní výchovné činnosti tř́dního učitele. Brno: Masarykova univerzita.

Střelec, S. (1999). Dovednosti, umožňující efektivní kooperaci s rodiči žáků. Pedagogická orientace, $18(4), 128-132$.

Střelec, S., \& Krátká, J. (2006). Činnosti třídního učitele z pohledu vedení škol. In Současné metodologické př́stupy a strategie pedagogického výzkumu. Sborník příspěvkü z XIV. konference ČAPV (s. 36-44). Plzeň: ČAPV.

Střelec, S., \& Krátká, J. (2007) Názory třídních učitelů na způsoby ovlivňování zdraví svých žáků. Brno: Paido. Dostupné z http://www.ped.muni.cz/z21/2006/konference_2006/ sbornik_2006/pdf/017.pdf

Střelec, S., \& Krátká, J. (2011). Názory učitelů na náročnost funkce třídního učitele. In A. Wiegerová \& S. Vávrová (Eds.), Učitelovo myslenie a uvažovanie (s. 48-60). Bratislava: OZ V4.

Sutton, R. E., \& Wheatley, K. F. (2003). Teachers' emotions and teaching: A review of the literature and directions for future research. Educational Psychology Review, 15(4), 327-358.

Šed'ová, K. (2013). Humor ve škole. Brno: Masarykova univerzita.

Šed'ová, K. (2015). Moc v dialogickém vyučování. Pedagogická orientace, 25(1), 32-62.

Švaříček, R. (2009). Narativní a sociální konstrukce profesní identity učitele experta (Disertační práce). Brno: Masarykova univerzita.

Švec, V., Vyskočilová, E., Nezvalová, D., Řezáč, J., Urbanovská, E., \& Chrástka, M. (2002). Cesty k učitelské profesi: utváření a rozvíjení pedagogických dovedností. Brno: Paido.

Tobin, K., Ritchie, S. M., Oakley, J. L., Mergard, V., \& Hudson, P. (2013). Relationships between emotional climate and the fluency of classroom interactions. Learning Environments Research, 16(1), 71-89.

Vašutová, J. (2004). Profese učitele v českém vzdělávacím kontextu. Brno: Paido.

Walterová, E. (2001). Učitelé jako profesní skupina, jejich vzdělávání a podpůrný systém. Praha: Univerzita Karlova.

Wubbels, T., \& Brekelmans, M. (2005). Two decades of research on teacher-student relationships in class. International Journal of Educational Research, 43(1), 6-24.

Wubbels, T., Créton, H. A., \& Hooymayers, H. P. (1987). A school-based teacher induction programme. European Journal of Teacher Education, 10(1), 81-94.

Wubbels, T., \& Levy, J. (1993). Do you know what you look like? Interpersonal relationships in education. London: Psychology Press.

Zins, J. E., Weissberg, R. P., Wang, M. C., \& Walberg. H. J. (Eds.). (2004). Building academic success on social and emotional learning: What does the research say? New York: Teachers College Press.

\section{Autorka}

Mgr. Alena Bendová, Masarykova univerzita, Pedagogická fakulta, Katedra pedagogiky, Poříčí 31, 60300 Brno, e-mail: 12845@mail.muni.cz 


\title{
Class teacher in social relations with his students: A case study
}

\begin{abstract}
The aim of the study is to analyse the determinants of a good relationship between a class teacher and the pupils at a vocational school. We focus on the class teacher. The data are part of a case study of a secondary school class with a good social climate. The first part is dedicated to theoretical foundations. We proceed mainly from the research of teacher expertise and the research of the relationships between the teachers and the students. In the second part of the paper we present partial results of a case study of a secondary class with a good social climate exclusively related to the class teacher. The sample consisted of 24 pupils and one class teacher. On the basis of the data analysis we identified on one side the personal characteristics of the teacher for building optimal relationship with the pupils (care, generosity, being extrovert and self-confident, life experience and youthfulness) and on the other side we identified the typical inter-personal behaviour to the pupils (expressive communication, encouragement, non-formal teaching, care and support, open expression of emotions, listening to and sharing personal information, application of influence).
\end{abstract}

Keywords: class teacher, social relationship, pupils, expert

Wiegerová, A. et al. (2015). Profesionalizace učitele mateřské školy z pohledu reformy kurikula. Zlín: FHS UTB.

Monografie se zabývá problematikou profesionalizace učitele mateřské školy a jejího kurikula. Je výsledkem spolupráce několika pracovních týmů z různých univerzitních pracovišt' v České republice i na Slovensku. Prezentuje empirická zjištění dílčích výzkumů, které reflektují zkušenosti učitelů mateřské školy z jejich praxe. Publikace je členěna do deseti kapitol, přičemž prvních osm je zaměřeno na profesionalizaci učitelů a poslední dvě na téma proměny kurikula předškolního vzdělávání v České republice i zahraničí. Monografie svými výstupy otevírá nové perspektivy v pregraduální přípravě učitelů mateřských škol. Zvláště významný je prostor věnovaný vzdělávání dětí do tři let a také nastavení možností proměn kurikula ve vztahu k výzvám OECD. 